OPEN ACCESS

Edited by:

Soumyajit Roy

Indian Institute of Science Education and Research Kolkata, India

Reviewed by:

Graham Newton,

University of Nottingham,

United Kingdom

Samar Kumar Das,

University of Hyderabad, India

*Correspondence:

Greta R. Patzke

greta.patzke@chem.uzh.ch

J. R. Galan-Mascaros jrgalan@iciq.es

Specialty section:

This article was submitted to Inorganic Chemistry,

a section of the journal

Frontiers in Chemistry

Received: 30 April 2018

Accepted: 03 July 2018

Published: 14 August 2018

Citation:

Soriano-López J, Song F, Patzke GR and Galan-Mascaros JR (2018) Photoinduced Oxygen Evolution Catalysis Promoted by Polyoxometalate Salts of Cationic Photosensitizers. Front. Chem. 6:302. doi: 10.3389/fchem.2018.00302

\section{Photoinduced Oxygen Evolution Catalysis Promoted by Polyoxometalate Salts of Cationic Photosensitizers}

\author{
Joaquín Soriano-López ${ }^{1,2}$, Fangyuan Song ${ }^{3}$, Greta R. Patzke ${ }^{3 *}$ and \\ J. R. Galan-Mascaros ${ }^{1,4 *}$ \\ ${ }^{1}$ Institute of Chemical Research of Catalonia, Barcelona Institute of Science and Technology, Tarragona, Spain, \\ ${ }^{2}$ Departament de Química Física i Inorgànica, Universitat Rovira i Virgili, Tarragona, Spain, ${ }^{3}$ Department of Chemistry, \\ University of Zurich, Zurich, Switzerland, ${ }^{4}$ ICREA, Passeig Lluis Companys, Barcelona, Spain
}

The insoluble salt $\mathrm{Cs}_{15} \mathrm{~K}\left[\mathrm{Cog}\left(\mathrm{H}_{2} \mathrm{O}\right)_{6}(\mathrm{OH})_{3}\left(\mathrm{HPO}_{4}\right)_{2}\left(\mathrm{PW}_{9} \mathrm{O}_{34}\right)_{3}\right]\left(\mathbf{C s C o g}_{\mathbf{9}}\right)$ is tested as heterogeneous oxygen evolution catalyst in light-induced experiments, when combined with the homogeneous photosensitizer $\left[\mathrm{Ru}(\mathrm{bpy})_{3}\right]^{2+}$ and the oxidant $\mathrm{Na}_{2} \mathrm{~S}_{2} \mathrm{O}_{8}$ in neutral $\mathrm{pH}$. Oxygen evolution occurs in parallel to a solid transformation. Post-catalytic essays indicate that the $\mathbf{C s C o}_{\mathbf{g}}$ salt is transformed into the corresponding $\left[\mathrm{Ru}(\mathrm{bpy})_{3}\right]^{2+}$ salt, upon cesium loss. Remarkably, analogous photoactivated oxygen evolution experiments starting with the $\left[\mathrm{Ru}(\mathrm{bpy})_{3}\right]_{(5+\mathrm{x})} \mathrm{K}_{(6-2 \mathrm{x})}\left[\mathrm{Cog}\left(\mathrm{H}_{2} \mathrm{O}\right)_{6}(\mathrm{OH})_{3}\left(\mathrm{HPO}_{4}\right)_{2}\left(\mathrm{PW}_{9} \mathrm{O}_{34}\right)_{3}\right] \cdot(39+\mathrm{x}) \mathrm{H}_{2} \mathrm{O}$ (RuCog) salt demonstrate much higher efficiency and kinetics. The origin of this improved performance is at the cation-anion, photosensitizer-catalyst pairing in the solid state. This is beneficial for the electron transfer event, and for the long-term stability of the photosensitizer. The latter was confirmed as the limiting process during these oxygen evolution reactions, with the polyoxometalate catalyst exhibiting robust performance in multiple cycles, upon addition of photosensitizer, and/or oxidant to the reaction mixture.

Keywords: water splitting, oxygen evolution, polyoxometalates, photosensitizer, cobalt

\section{INTRODUCTION}

Sunlight is the preferred carbon-neutral energy source for competing with fossil fuels for energy production, because solar radiation is readily accessible at almost any location on the surface of the Earth (Cook et al., 2010). Artificial photosynthesis aims to mimic natural photosynthesis, where sunlight is stored in the form of chemical bonds through reduction of $\mathrm{CO}_{2}$ into sugars, employing $\mathrm{H}_{2} \mathrm{O}$ as the ultimate source of electrons (Mcevoy and Brudvig, 2006). Therefore, an artificial photosynthesis device would convert sunlight into spatially separated electron/hole pairs and store its energy subsequently into chemical bonds by means of water splitting, obtaining hydrogen as a clean fuel together with oxygen as the only side product (Lewis and Nocera, 2006; Balzani et al., 2008; Barber, 2009). Unfortunately, the market introduction of commercial artificial photosynthesis devices is still hampered by the lack of robust, inexpensive and efficient water oxidation catalysts (WOCs) (Dau et al., 2010; Seh et al., 2017). 
Over the last decades, scientists have reported a wide variety of new WOCs. Homogeneous organometallic compounds work at fast oxygen evolution rates and offer good processability (Concepcion et al., 2008, 2009; Bozoglian et al., 2009; Blakemore et al., 2010; Xu et al., 2010; Lloret-Fillol et al., 2011; Mccool et al., 2011; Barnett et al., 2012; Duan et al., 2012; Liu and Wang, 2012; Zhang et al., 2013; Goberna-Ferrón et al., 2014). However, they often suffer from limited long-term stability due to oxidative degradation of the organic ligands in the harsh working conditions needed for water oxidation. Precious-metal-based WOCs, for instance Ir-, and Ru-based materials, have shown superior performance and stability for water oxidation catalysis (Pillai et al., 2000; Youngblood et al., 2009; Blakemore et al., 2010; Duan et al., 2012). Unfortunately, the high production price due to metal scarcity questions their viable implementation into commercial devices. Earth abundant transition metal oxides and perovskites are a robust alternative, but exclusively in alkaline media (Galán-Mascarós, 2015). Therefore, alternatives to the current state-of-the-art catalysts are needed.

Polyoxometalates (POMs) have recently appeared as a promising new catalyst class (Geletii et al., 2008; Sartorel et al., 2008). When employed as WOCs, they combine the most appealing features of homogeneous and heterogeneous materials, and many of them can be obtained from inexpensive raw materials. They are all-inorganic molecular clusters with high stability under strongly oxidizing conditions. At the same time, their molecular nature provides access to the tunability and superior processing capabilities of homogeneous catalysts for their easier implementation into devices (Pope, 1983; Pope and Müller, 2001). POMs have shown high catalytic activity in water oxidation over a remarkable $\mathrm{pH}$ range (0-10), and they retain their catalytic activity under heterogeneous conditions as their corresponding insoluble salts, or when anchored onto solid supports (Wu et al., 2012; Guo et al., 2013; Quintana et al., 2013; Soriano-López et al., 2013).

Among polyoxometalates, the cobalt-containing POMs (CoPOMs) have emerged as the most promising WOCs due to their high efficiency and kinetics (Goberna-Ferrón et al., 2012; Lv et al., 2012, 2014; Evangelisti et al., 2013). After Hill et al. reported the OER activity of the $\left[\mathrm{Co}_{4}\left(\mathrm{H}_{2} \mathrm{O}\right)_{2}\left(\mathrm{PW}_{9} \mathrm{O}_{34}\right)_{2}\right]^{10-}$ polyanion (Yin et al., 2010; Huang et al., 2011; Stracke and Finke, 2011, 2013,2014), we turned our attention to the high nuclearity $\left[\mathrm{Co}_{9}\left(\mathrm{H}_{2} \mathrm{O}\right)_{6}(\mathrm{OH})_{3}\left(\mathrm{HPO}_{4}\right)_{2}\left(\mathrm{PW}_{9} \mathrm{O}_{34}\right)_{3}\right]^{16-}$ (Goberna-Ferrón et al., 2012, 2015; Soriano-López et al., 2013; Cog, Figure 1). Cog shows good activity for photo-assisted water oxidation in homogeneous conditions, exhibiting fast charge transfer kinetics with the model $\left[\mathrm{Ru}(\mathrm{bpy})_{3}\right]^{2+}$ photosensitizer (bpy $=1,2$-dipyridyl; Natali et al., 2017). It is also active in the solid state when processed as an insoluble salt with alkaline metal countercations (Soriano-López et al., 2013).

In this work we report the next required step on the road to technological applications for $\mathrm{Co}_{9}$ in an artificial photosynthesis platform, namely its combination with a photosensitizer in a light-induced process in heterogeneous conditions. These essays have been very successful with other POMs and

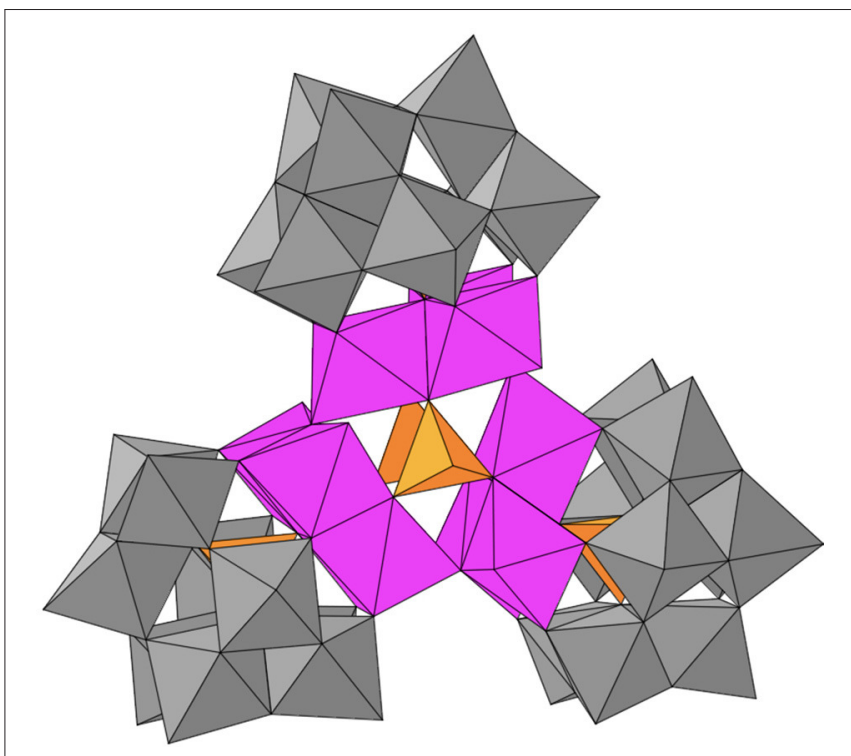

FIGURE 1 | Polyhedral representation of the polyanion $\left[\mathrm{Cog}\left(\mathrm{H}_{2} \mathrm{O}\right)_{6}(\mathrm{OH})_{3}\left(\mathrm{HPO}_{4}\right)_{2}\left(\mathrm{PW}_{9} \mathrm{O}_{34}\right)_{3}\right]^{16-}\left(\mathbf{C o}_{\mathbf{9}}\right) ; \mathrm{WO}_{6}$, gray octahedra; $\mathrm{PO}_{4}$, orange tetrahedra; $\mathrm{CoO}_{6}$, pink octahedra.

water oxidation catalysts to assess photo-induced catalytic performance, mechanistic considerations, and stability issues (Puntoriero et al., 2010; Gao et al., 2013; Sartorel et al., 2013; Al-Oweini et al., 2014; Xiang et al., 2014; Natali et al., 2017). Our experiments confirm the efficient electron transfer between catalyst and sensitizer, even when both species are combined into an insoluble salt. The latter opens up interesting possibilities for future combinations of cationic photosensitizers with polyanionic WOCs for the construction of compact functional photoelectrodes.

\section{EXPERIMENTAL SECTION}

\section{Materials and Synthesis}

Tris(2,2' -bipyridyl)dichlororuthenium(II) hexahydrate and sodium persulfate were purchased from TCI and Sigma-Aldrich ( $>99 \%$ purity) and used without further purification. The synthesis of $\mathrm{Cs}_{15} \mathrm{~K}\left[\mathrm{Co}_{9}\left(\mathrm{H}_{2} \mathrm{O}\right)_{6}(\mathrm{OH})_{3}\right.$ $\left.\left(\mathrm{HPO}_{4}\right)_{2}\left(\mathrm{PW}_{9} \mathrm{O}_{34}\right)_{3}\right] \cdot 39 \mathrm{H}_{2} \mathrm{O}\left(\mathbf{C s C o g}_{9}\right)$ was already reported (Soriano-López et al., 2013). $\quad\left[\mathrm{Ru}(\mathrm{bpy})_{3}\right]_{(5+\mathrm{x})} \mathrm{K}_{(6-2 \mathrm{x})}\left[\mathrm{Co}_{9}\right.$ $\left.\left(\mathrm{H}_{2} \mathrm{O}\right)_{6}(\mathrm{OH})_{3}\left(\mathrm{HPO}_{4}\right)_{2}\left(\mathrm{PW}_{9} \mathrm{O}_{34}\right)_{3}\right] \cdot(39+\mathrm{x}) \mathrm{H}_{2} \mathrm{O}$ (RuCog) was prepared by metathesis: A stoichiometric excess of $\left[\mathrm{Ru}(\mathrm{bpy})_{3}\right] \mathrm{Cl}_{2}$ was added to a solution containing $\mathrm{Na}_{8} \mathrm{~K}_{8}\left[\mathrm{Co}_{9}\left(\mathrm{H}_{2} \mathrm{O}\right)_{6}(\mathrm{OH})_{3}\left(\mathrm{HPO}_{4}\right)_{2}\left(\mathrm{PW}_{9} \mathrm{O}_{34}\right)_{3}\right] \cdot 43 \mathrm{H}_{2} \mathrm{O} \quad(\mathbf{K C o})$. $\mathrm{RuCo}_{9}$ immediately precipitated as an orange powder. It was filtered, washed with water and acetone, and air-dried.

\section{Material Characterizations}

Elemental CHN analysis was performed with an Elemental Microanalyzer Flash model 1112. Detection of $\mathrm{Co}, \mathrm{Ru}$, and $\mathrm{W}$ was performed on an inductively coupled plasma atomic emission spectrometer iCap 6500 (Thermo Fisher Scientific), and 
K was detected on a 2,380 atomic absorption spectrophotometer (Perkin-Elmer), both by Mikroanalytisches Labor Pascher (Remagen/Germany). Thermogravimetric analyses were performed with powder samples using a TGA/SDTA851 Mettler Toledo with a MT1 microbalance. Dynamic light scattering was used to measure the particle size distribution employing a Malvern NanoZS analyzer. FT-IR spectra were collected in the $3600-400 \mathrm{~cm}^{-1}$ range with a Bruker Optics FTIR Alpha spectrometer equipped with a DTGS detector and a $\mathrm{KBr}$ beamsplitter at $4 \mathrm{~cm}^{-1}$ resolution. Raman measurements were acquired using a Renishaw inVia Reflex Raman confocal microscope (Gloucestershire, UK) equipped with a diode laser emitting at $785 \mathrm{~nm}$ at a nominal power of $300 \mathrm{~mW}$, and a Peltier-cooled CCD detector $\left(-70^{\circ} \mathrm{C}\right)$ coupled to a Leica DM-2500 microscope. X-ray photoelectron spectroscopy (XPS) (K-ALPHA, Thermo Scientific SSTTI at University of Alicante) was used to analyze the surface of the samples. All spectra were collected using $\mathrm{Al}-\mathrm{K}_{\alpha}$ radiation $(1486.6 \mathrm{eV})$, monochromatized by a twin crystal monochromator, yielding a focused X-ray spot with a diameter of $400 \mu \mathrm{m}$, at $3 \mathrm{~mA} \times 12 \mathrm{kV}$. The alpha hemispherical analyzer was operated in the whole energy band, and $50 \mathrm{eV}$ in a narrow scan to selectively measure the particular elements.

\section{Photoinduced Water Oxidation Catalysis}

Oxygen evolution experiments were performed in a $6.7 \mathrm{~mL}$ headspace Schlenk tube sealed with a rubber septum (PFTE). The Schlenk tube was covered with aluminum foil, in order to avoid an early light-induced reaction of the system, and filled with $1 \mathrm{mM}(9.4 \mathrm{mg}) \quad\left[\mathrm{Ru}(\mathrm{bpy})_{3}\right] \mathrm{Cl}_{2}, 5 \mathrm{mM}$ (14.9 mg) $\mathrm{Na}_{2} \mathrm{~S}_{2} \mathrm{O}_{8}$, the desired amount of catalyst, and $12.5 \mathrm{~mL}$ of $40 \mathrm{mM} \mathrm{KP}$ i buffer solution at $\mathrm{pH}$ 7.0. Experiments employing the $\mathbf{R u C o}_{9}$ salt as catalyst were performed with and without addition of $\left[\mathrm{Ru}(\mathrm{bpy})_{3}\right] \mathrm{Cl}_{2}$, the former for comparison in the same conditions required for $\mathrm{Co}_{3} \mathrm{O}_{4}$ experiments. Suspensions were completely deaerated by purging with nitrogen. A baseline of $20 \mathrm{~min}$ was recorded to ensure that no oxygen leakage or side reactions took place. Next, the system was exposed to the light of a blue LED lamp (wavelength at peak emission $=465 \mathrm{~nm}$; OSRAM Opto Semiconductors) working at $0.20 \mathrm{~A}$ and $11.4 \mathrm{~V}$. The concentration of oxygen in the headspace was measured by employing a $\mathrm{O}_{2}$-sensor probe (Ocean Optics NeoFOX oxygen-sensing system equipped with a FOXY probe). Turnover number (TON) and turnover frequency (TOF) were estimated per $\mathrm{Cog}_{9}$ content as obtained from chemical analyses on fresh compounds (see SI).

\section{RESULTS AND DISCUSSION}

\section{Visible-Light-Driven Water Oxidation by $\mathrm{CsCo}_{9}$ in Heterogeneous Conditions}

Water oxidation experiments were carried out with $\left[\mathrm{Ru}(\mathrm{bpy})_{3}\right]^{2+}$ as a model photosensitizer and $\mathrm{S}_{2} \mathrm{O}_{8}^{2-}$ as sacrificial electron acceptor, in a suspension of the insoluble salt $\mathrm{Cs}_{15} \mathrm{~K}\left[\mathrm{Co}_{9}\left(\mathrm{H}_{2} \mathrm{O}\right)_{6}(\mathrm{OH})_{3}\left(\mathrm{HPO}_{4}\right)_{2}\left(\mathrm{PW}_{9} \mathrm{O}_{34}\right)_{3}\right]$ (CsCo9). Light irradiation $(\lambda>400 \mathrm{~nm})$ of this mixture

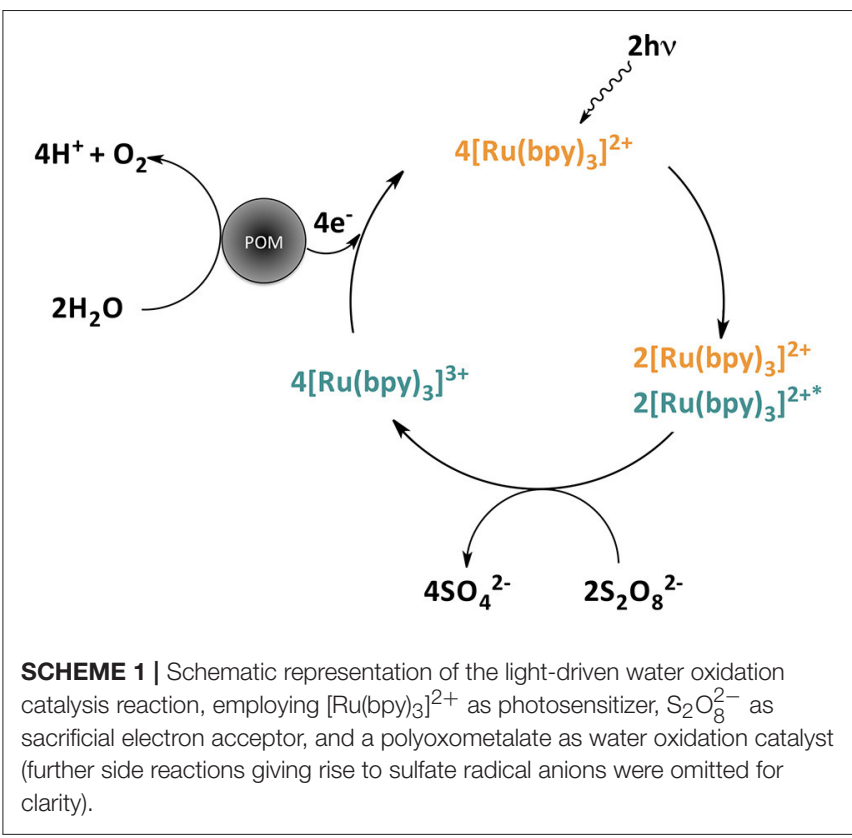

promotes oxygen evolution, which was monitored using a fluorescence $\mathrm{O}_{2}$-sensor probe for increasing amounts of $\mathrm{CsCo}_{9}$ (1-50 mg). The proposed net reaction mechanism for light-driven water oxidation catalyzed by POMs is depicted in Scheme 1. No oxygen evolution was detected in the absence of any of the components.

The reaction starts with fast kinetics immediately after light irradiation, and slows down until oxygen evolution stops reaching a plateau after $2 \mathrm{~h}$. We analyzed the oxygen production as a function of catalyst content (Figure 2 and Table 1). The highest values of turnover number (TON) and turnover frequency (TOF) obtained were 14.2 and $10.8 \mathrm{~h}^{-1}$, for the minimum quantity used $(1 \mathrm{mg}, \approx 0.1 \mu \mathrm{mol})$. In terms of chemical yield (CY, see SI), a maximum 9.2\% was reached for intermediate $\mathrm{CsCo}_{9}$ contents $(10 \mathrm{mg}, \approx 1 \mu \mathrm{mol})$ in the investigated range. After oxygen evolution, $\mathrm{CsCo}_{9}$ was recovered from the reaction vessel to perform structural characterization. The FT-IR spectrum shows the typical Cog bands within the $1,100-400 \mathrm{~cm}^{-1}$ range, identical to those observed with the freshly made CsCog. We also found additional bands in the region between 1,200 and $1,600 \mathrm{~cm}^{-1}$, which can be attributed to the bipyridyl (bpy) ligand (Figure S1). The same information is obtained from the Raman spectra (Figure S2). Moreover, comparison of the XPS spectra (Figure S3) showed the appearance of intense $\mathrm{Ru}$ peaks in the recovered CsCog, and disappearance of the expected Cs peak (Figure S4). The data in their entirety suggest that cation exchange occurred under turnover conditions, i.e., $\mathrm{Cs}^{+}$cations are replaced by $\left[\mathrm{Ru}(\mathrm{bpy})_{3}\right]^{2+}$ cations. Indeed, the Raman spectrum of the recovered $\mathrm{CsCo}_{9}$ is reminiscent of the corresponding Raman spectrum of the salt obtained by addition of an excess of $\left[\mathrm{Ru}(\mathrm{bpy})_{3}\right] \mathrm{Cl}_{2}$ to an aqueous $\mathrm{K}_{16} \mathrm{Cog}_{9}$ solution (Figure $\mathbf{S 9}$ ). 


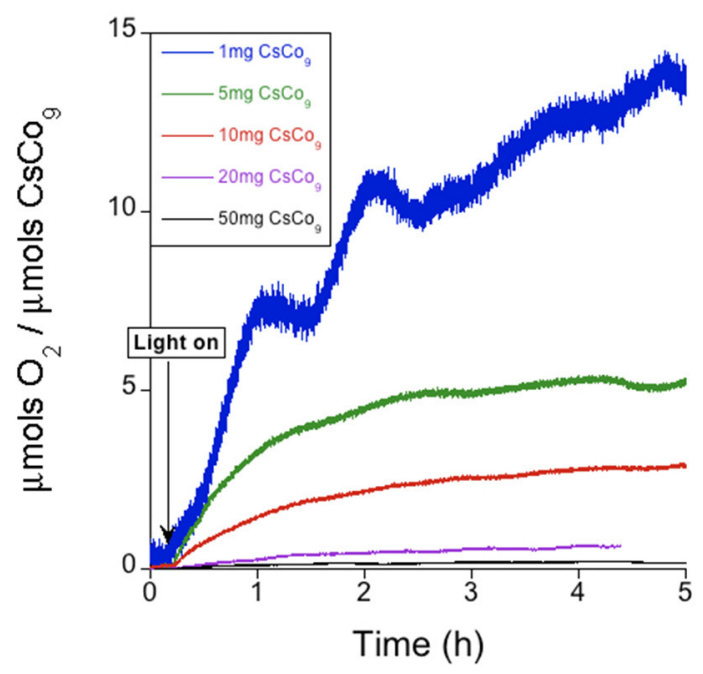

FIGURE 2 | Oxygen evolution profile of the $\mathbf{C s C o}_{\mathbf{9}}$ salt in $\mathrm{KPi}(40 \mathrm{mM})$ buffer at $\mathrm{pH} 7$, with $\left[\mathrm{Ru}(\mathrm{bpy})_{3}\right]^{2+}(1 \mathrm{mM})$ and $\mathrm{S}_{2} \mathrm{O}_{8}^{2-}(5 \mathrm{mM})$.

TABLE 1 | Comparison of visible-light-driven oxygen evolution performance of $\mathrm{CsCo}_{9}$ and $\mathbf{R u C o g}_{\mathbf{g}}$ catalysts $^{(\mathrm{a})}$.

\begin{tabular}{llccccc}
\hline POM & Catalyst (mg) & $\mathbf{1}$ & $\mathbf{5}$ & $\mathbf{1 0}$ & $\mathbf{2 0}$ & $\mathbf{5 0}$ \\
\hline \multirow{2}{*}{ CsCog (first run) } & TON & 14.2 & 5.3 & 2.9 & 0.7 & 0.2 \\
& TOF $\left(\mathrm{h}^{-1}\right)$ & 10.8 & 4.0 & 1.4 & 0.3 & 0.2 \\
& CY $(\%)$ & 4.4 & 8.4 & 9.2 & 4.0 & 3.6 \\
\hline \multirow{2}{*}{ RuCog } & TON & 27.3 & 20.3 & 16.7 & 7.2 & 2.7 \\
& TOF $\left(\mathrm{h}^{-1}\right)$ & 19.1 & 11.9 & 17.0 & 9.0 & 4.3 \\
& CY $(\%)$ & 7.6 & 28.4 & 47.6 & 42.4 & 36.4 \\
\hline POM & Catalyst $(\mu \mathrm{m})$ & 0.1 & 0.5 & 1 & 2 & 5
\end{tabular}

aTON, total turnover number after completion of the reaction; TOF, slope of the oxygen evolution curve at the starting time; CY, total chemical yield after completion of the reaction.

\section{Visible-Light-Driven Water Oxidation by $\mathrm{RuCo}_{9}$ in Heterogeneous Conditions}

Addition of an excess of $\left[\mathrm{Ru}(\mathrm{bpy})_{3}\right] \mathrm{Cl}_{2}$ to an aqueous $\mathrm{KCo}_{9}$ solution forms immediately an insoluble precipitate. The presence of the $\left[\mathrm{Ru}(\mathrm{bpy})_{3}\right]^{2+}$ cation and the $\left[\mathrm{Co}_{9}\left(\mathrm{H}_{2} \mathrm{O}\right)_{6}(\mathrm{OH})_{3}\left(\mathrm{HPO}_{4}\right)_{2}\left(\mathrm{PW}_{9} \mathrm{O}_{34}\right)_{3}\right]^{16-}$ anion were confirmed by FT-IR spectroscopy (Figure S8) with the signature bands for both molecular species. However, the exact stoichiometry was difficult to completely assess. We carried out elemental CHN analyses, and metal ICP analyses, along with thermogravimetry analyses, and they were not fully consistent (Table S1). It is worthy to note at this point that our attempts to crystallize this compound in order to accurately characterize its composition and structure failed, because slow diffusion between solutions of cation and anion produce insoluble single crystals of the compound $\left[\mathrm{Ru}(\mathrm{bpy})_{3}\right]_{2} \mathrm{~K}_{12}\left[\mathrm{Co}_{9}\left(\mathrm{H}_{2} \mathrm{O}\right)_{6}(\mathrm{OH})_{3}\left(\mathrm{HPO}_{4}\right)_{2}\left(\mathrm{PW}_{9} \mathrm{O}_{34}\right)_{3}\right] \cdot \mathrm{xH}_{2} \mathrm{O}$

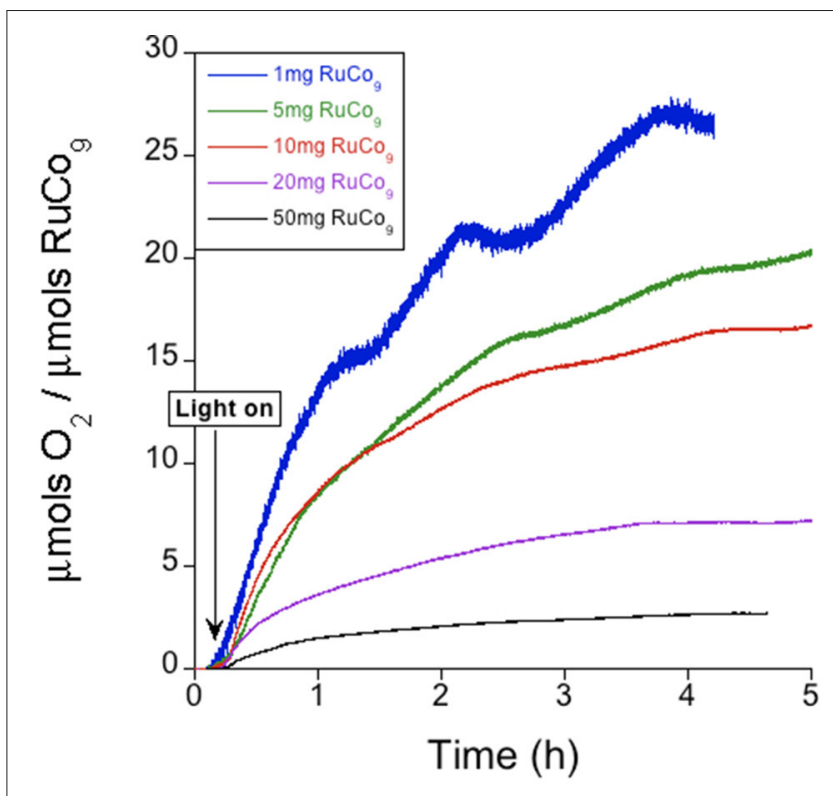

FIGURE 3 | Oxygen evolution profile for solid $\mathbf{R u C o}$ in $\mathrm{KP}_{\mathrm{i}}(40 \mathrm{mM})$ buffer at $\mathrm{pH} 7$ with $\mathrm{S}_{2} \mathrm{O}_{8}^{2-}(5 \mathrm{mM})$.

(Table S2, Figure S13). This Ru/POM stoichiometry is far too low in comparison with our RuCog analyses (Table S1), and thus it is not representative of the $\mathrm{RuCo}_{9}$ catalyst. The obtention of this crystalline phase, though, precludes the isolation of other salts with higher $\left[\mathrm{Ru}(\mathrm{bpy})_{3}\right]^{2+}$ content, closer to the present $\mathbf{R u C o g}$ solid. The most plausible explanation is that $\mathbf{R u C o g}$ actually consists of a mixture of different $\left[\mathrm{Ru}(\mathrm{bpy})_{3}\right] / \mathrm{Cog}_{9}$ salts, and their slightly different solubility and composition gives small deviations depending on the given analytical technique. With all the analytical data taken into account (Table S1), we assign an average stoichiometry $\left[\mathrm{Ru}(\text { bpy })_{3}\right]_{(5+\mathrm{x})} \mathrm{K}_{(6-2 \mathrm{x})}\left[\mathrm{Co}_{9}\left(\mathrm{H}_{2} \mathrm{O}\right)_{6}(\mathrm{OH})_{3}\left(\mathrm{HPO}_{4}\right)_{2}\left(\mathrm{PW}_{9} \mathrm{O}_{34}\right)_{3}\right]$. $(39+\mathrm{x}) \mathrm{H}_{2} \mathrm{O}$ (RuCo9), where $-1<\mathrm{x}<1$ (see Table S1 and Figure S5). This powder is insoluble in water at room temperature with an average particle size of $374 \mathrm{~nm}$ (Figure S6).

When a suspension of $\mathbf{R u C o}_{9}$ in a solution of $\mathrm{S}_{2} \mathrm{O}_{8}^{2-}$ is irradiated $(\lambda>400 \mathrm{~nm})$, oxygen evolution starts. In this case, the proposed reaction mechanism is analogous to that depicted in Scheme 1, but with photosensitizer and catalyst bound together in the solid state through electrostatic cationanion interactions. Remarkably, the measured oxygen evolution in these conditions (Figure 3) is significantly superior to the first run starting from photosensitizer in solution (Table 1 and Figure 4). The maximum TON (27.3) and TOF (19.1 $\mathrm{h}^{-1}$ ) values are doubled, and the CY showed a remarkable increase up to $47.6 \%$. Pulsed experiments confirmed that oxygen evolves exclusively when the light source is switched on (Figure S7).

\section{Stability of the RuCog System}

In order to determine the limiting agent in the photo-assisted oxygen evolution reaction, we carried out different tests. 

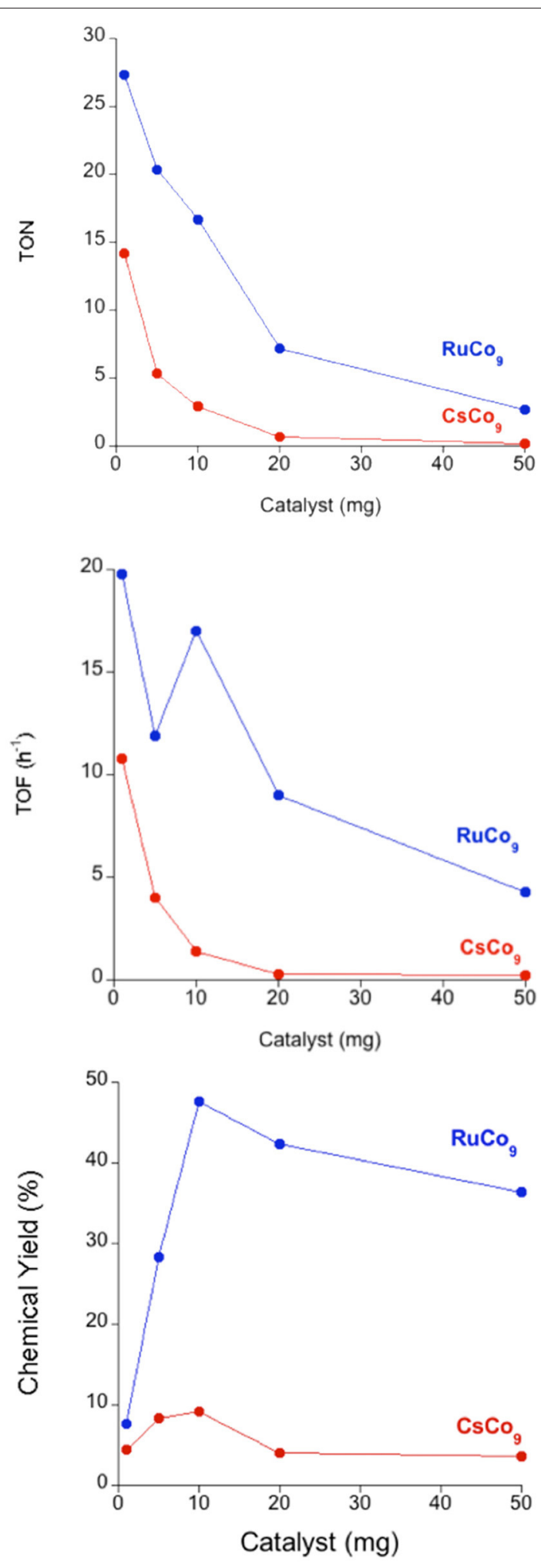

FIGURE 4 | Comparison of TON, TOF, and chemical yield (CY) for RuCog (blue) and $\mathbf{C s C o}_{9}$ (red). Experiments were carried out in a KPi (40 mM) buffer at $\mathrm{pH} 7$, with $\mathrm{S}_{2} \mathrm{O}_{8}^{2-}(5 \mathrm{mM})$. $\left[\mathrm{Ru}(\mathrm{bpy})_{3}\right]^{2+}(1 \mathrm{mM})$ was added to the suspension of $\mathbf{C s C o}_{\mathbf{g}}$, whereas no homogeneous photosensitizer was added for the $\mathbf{R u C o}_{\mathbf{g}}$ catalyst.

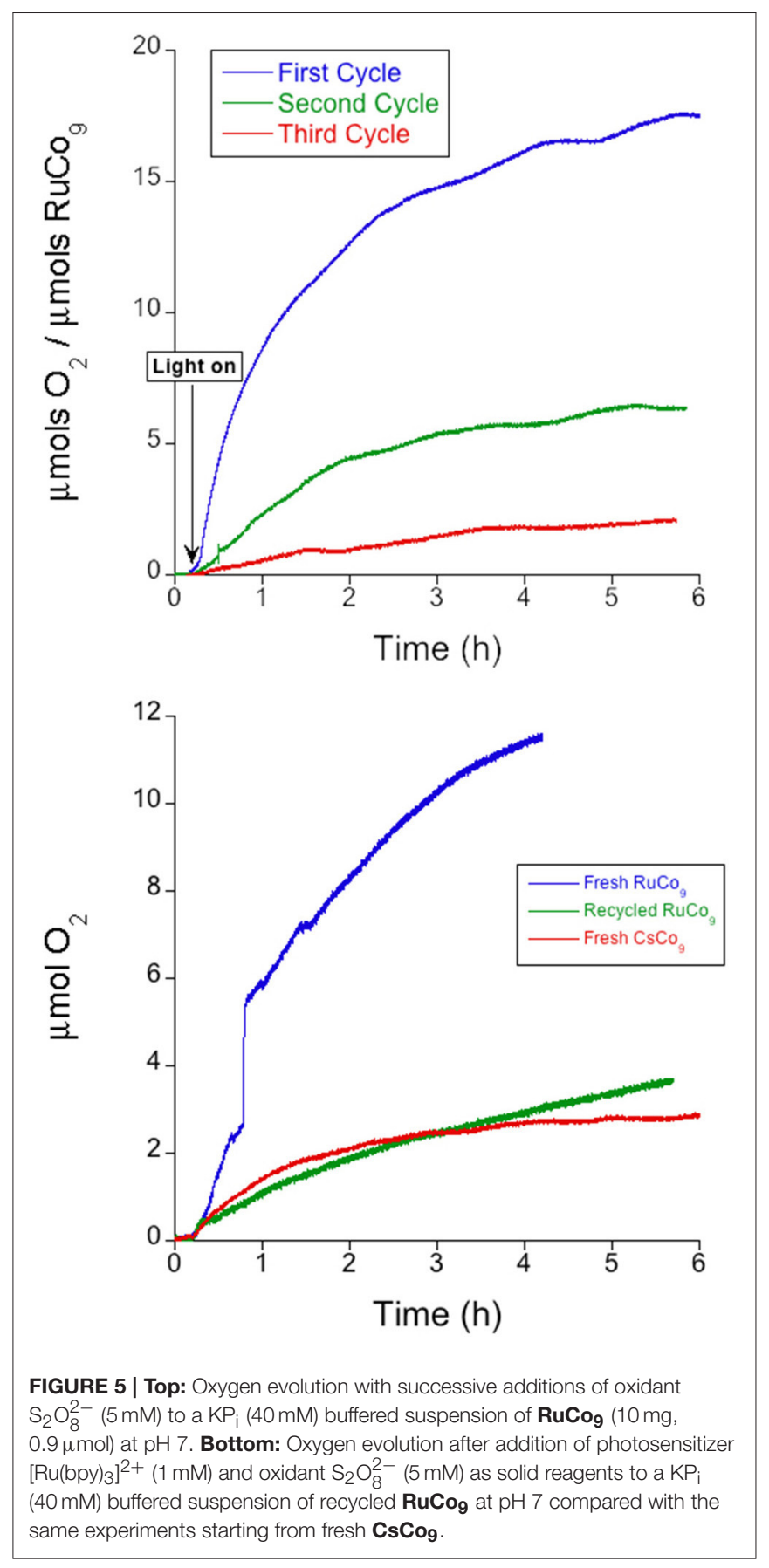

Successive additions of $\mathrm{S}_{2} \mathrm{O}_{8}^{2-}$ to the as-used RuCog suspension indicate that oxygen evolution activity is severely affected after each cycle (Figure 5 and Table 2), i.e., the system can barely perform three cycles before reaching complete deactivation. After deactivation, addition of an aliquot containing the photosensitizer $\left[\mathrm{Ru}(\mathrm{bpy})_{3}\right]^{2+}$ and $\mathrm{S}_{2} \mathrm{O}_{8}^{2-}$ to the reaction vessel restarts oxygen evolution, with rates and yields comparable to those obtained with $\mathrm{CsCo}_{9}$ (Figure 5). This behavior can only be explained with deactivation of the photosensitizer in $\mathbf{R u C o}_{9}$ recycling experiments, probably due to oxidative degradation of 
TABLE 2 | Comparison of the $\mathbf{R u C o}_{\mathbf{9}}$-catalyzed light-driven oxygen evolution performance obtained for successive addition of $\mathrm{S}_{2} \mathrm{O}_{8}^{2-}(5 \mathrm{mM})$ to the reaction vessel $^{\mathrm{a}}$.

\begin{tabular}{lccc}
\hline & TON & TOF $\left(\mathbf{h}^{-\mathbf{1}}\right)$ & CY (\%) \\
\hline 1st cycle & 16.7 & 17.0 & 47.6 \\
2nd cycle & 6.4 & 2.7 & 17.6 \\
3rd cycle & 2.1 & 0.7 & 5.6 \\
\hline
\end{tabular}

a TON, total turnover number at the final reaction time; TOF, slope of the oxygen evolution curve at the starting time; $\mathrm{CY}$, total chemical yield at the final reaction time.

the organic ligands, during the harsh working conditions. The catalytic POM appears to be robust, since its performance is maintained during successive cycles.

\section{Analysis of Adventitious $\mathrm{CoO}_{\mathrm{x}}$ Formation}

In water oxidation with cobalt-based catalysts, it is fundamental to rule out the in situ formation of cobalt oxide $\mathrm{CoO}_{\mathrm{x}}$, a competent heterogeneous WOC. This could occur through $\mathrm{Co}^{2+}$ leaching from the $\mathbf{R u C o}_{9}$ salt, and the subsequent formation of $\mathrm{CoO}_{\mathrm{x}}$ under oxidative conditions. Thus, we analyzed the as-used $\mathbf{R u C o}_{9}$ with different experimental techniques in the search for traces of $\mathrm{CoO}_{\mathrm{x}}$.

$\mathbf{R u C o}_{9}$ was recovered from the reaction vessel after the visible-light-driven water oxidation experiments. The signature FT-IR and Raman bands of the $\mathbf{C o}_{9}$ cluster remain identical when compared with pristine RuCog, suggesting that the bulk POM structure is maintained during the experiments. Raman spectroscopy is particularly suited to detect even traces of $\mathrm{CoO}_{\mathrm{x}}$ due to its high surface sensitivity, but no bands that could be assigned to a $\mathrm{CoO}_{\mathrm{x}}$ species are present (Figures S8-S10).

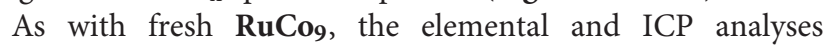
showed small deviations, making difficult to confirm final stoichiometry. The numbers are not too different from the original stoichiometry (Table S1). However, we need to point out that these analyses show a decrease for all elements, except for $\mathrm{W}$ that increases. We assign this surprising result to the deterioration of the compounds during working conditions [triggered by the $\left[\mathrm{Ru}(\mathrm{bpy})_{3}\right]^{2+}$ decomposition], making them even more insoluble, and untractable.

Another powerful surface-sensitive technique is XPS. Pristine and recovered $\mathrm{RuCo}_{9}$ salts display analogous XPS spectra (Figure S11). The presence of $\mathrm{CoO}_{\mathrm{x}}$ should include the appearance of a typical $\mathrm{Co}^{3+}$ peak below $780 \mathrm{eV}$ (Chuang et al., 1976; Tan et al., 1991; Hara et al., 2000). Close analysis of the $\mathrm{Co}$ and $\mathrm{O}$ edges in search of such features that could be assigned to the presence of an $\mathrm{CoO}_{\mathrm{x}}$ phase were negative. XPS spectra of RuCog before and after oxygen evolution show intense bands only in the $780-783 \mathrm{eV}$ range, which differ from those expected for $\mathrm{CoO}_{\mathrm{x}}$ (Figure S12). This indicates that no cobalt oxide amounts are formed during turnover conditions within the detection limit of these techniques.

In order to gather additional indirect proof of the absence of the significant participation of cobalt oxide impurities, we compared the photo-induced oxygen evolution reaction starting from the $\mathrm{RuCo}_{9}$ salt to the $\mathrm{Co}_{3} \mathrm{O}_{4}$ catalyst (Figure 6 and

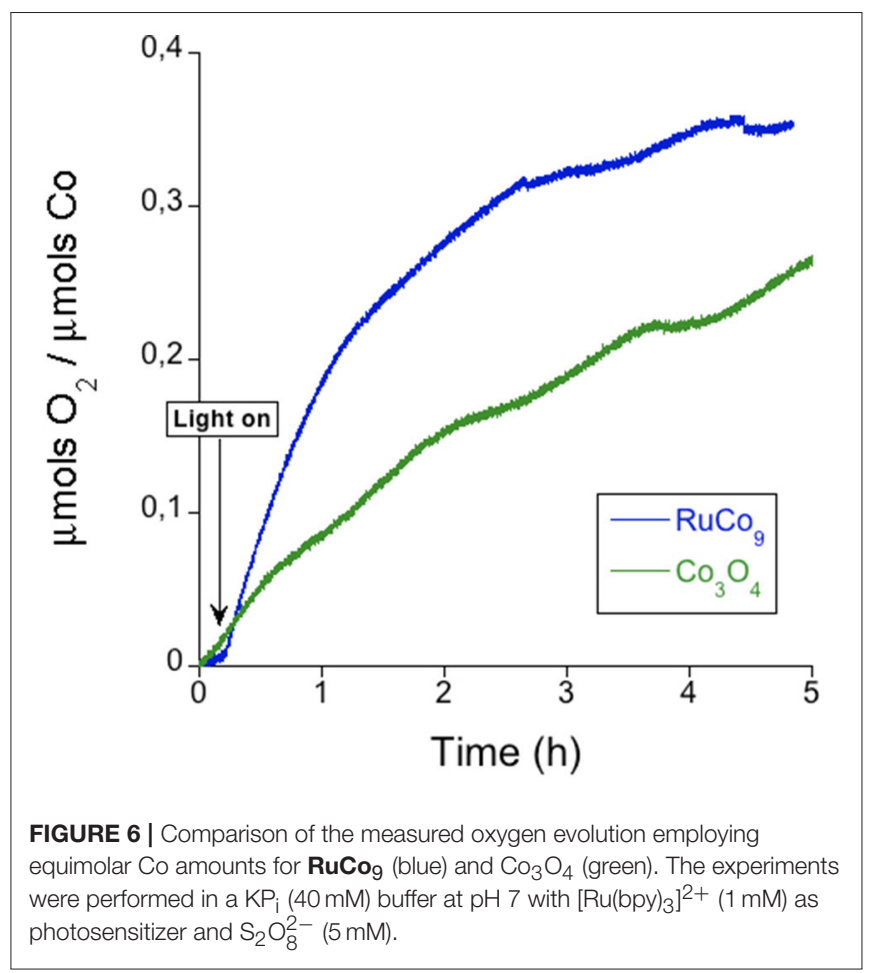

TABLE 3 | Comparison of the light-driven oxygen evolution data catalyzed by $\mathbf{R u C o}_{9}$ and by $\mathrm{Co}_{3} \mathrm{O}_{4}$ under the same reaction conditions ${ }^{\mathrm{a}, \mathrm{b}}$.

\begin{tabular}{lccc}
\hline Catalyst & TON & TOF $\left(\mathbf{h}^{-\mathbf{1}}\right)$ & CY (\%) \\
\hline RuCo $_{\mathbf{9}}$ & 3.2 & 2.3 & 17.2 \\
$\mathrm{Co}_{3} \mathrm{O}_{4}$ & 0.9 & 0.3 & 12.8 \\
\hline
\end{tabular}

a TON, total turnover number at the final reaction time; TOF, slope of the oxygen evolution curve at the starting time; CY, total chemical yield at the final reaction time.

${ }^{b}$ The experiments were performed in a $K P_{i}(40 \mathrm{mM})$ buffer at $\mathrm{pH} 7$ with $\left[\mathrm{Ru}(\mathrm{bpy})_{3}\right]^{2+}$ $(1 \mathrm{mM})$ as photosensitizer, $\mathrm{S}_{2} \mathrm{O}_{8}^{2-}(5 \mathrm{mM})$ as sacrificial electron acceptor, and with $13.99 \mu \mathrm{mols}$ of $\mathrm{Co}$ in the form of $\mathbf{R u C o}_{\mathbf{9}}$ or $\mathrm{Co}_{3} \mathrm{O}_{4}$.

Table 3). For equimolar conditions, RuCog displays an overall better performance, with faster onset kinetics and a higher efficiency. This is incompatible with the attribution of the catalytic activity observed for $\mathbf{R u C o g}_{9}$ to very small traces of $\mathrm{CoO}_{\mathrm{x}}$, which may be below the detection limit of Raman or XPS techniques.

\section{CONCLUSIONS}

We compared the heterogeneous catalytic activity of two different $\mathrm{Co}_{9}$ starting materials under visible-lightdriven water oxidation conditions at neutral $\mathrm{pH}$. Direct combination of $\mathrm{CsCog}_{9}$ with a homogeneous photosensitizer yields a maximum turnover number (TON) of 14.2 and a maximum turnover frequency (TOF) of $10.8 \mathrm{~h}^{-1}$ with oxygen yields around $10 \%$. Pre-catalytic incorporation of the cationic photosensitizer into the polyoxometalate salt through substitution of the alkali metal improves the oxygen 
evolution notably, affording chemical yields close to $50 \%$. We associate this improvement to two beneficial effects of photosensitizer immobilization. On the one hand, the closer cation-anion (photosensitizer/catalyst) interaction in the solid state facilitates electron transfer, and therefore enhances the oxygen evolution kinetics. Additionally, the incorporation of the photosensitizer into the solid state partially improves its stability, an additional benefit to increase the efficiency of the overall process.

Our experimental data indicate that oxygen evolution eventually stops due to decomposition of the photosensitizer. Successive additions of photosensitizer re-start the water oxidation reaction at consistent rates, supporting the stable catalytic performance of Cog. We carried out careful surface analyses on the as-used catalyst in the search of traces of cobalt oxide. Neither Raman nor XPS spectroscopy showed any feature that could be associated with $\mathrm{CoO}_{\mathrm{x}}$ species. Additionally, $\mathrm{RuCo}_{9}$ exhibits superior catalytic performance than $\mathrm{Co}_{3} \mathrm{O}_{4}$. Thus, the hypothetical presence of undetectable $\mathrm{CoO}_{\mathrm{x}}$ traces cannot be responsible for the observed catalytic activity. This supports the genuine catalytic activity of $\mathbf{R u C o}_{9}$ for photoinduced water oxidation as the first example, to the best of our knowledge, of an effective photosensitizer/catalyst electron transfer in an ionic salt. The superior performance of this ionic composite opens up interesting perspectives for the use of such materials in the development of compact photoanodes for artificial photosynthesis.

\section{REFERENCES}

Al-Oweini, R., Sartorel, A., Bassil, B. S., Natali, M., Berardi, S., Scandola, F., et al. (2014). Photocatalytic water oxidation by a mixed-valent $\mathrm{Mn}_{3}^{\mathrm{III}} \mathrm{Mn}^{\mathrm{IV}} \mathrm{O}_{3}$ manganese oxo core that mimics the natural oxygen-evolving center. Angew. Chem. Int. Ed. 53, 11182-11185. doi: 10.1002/anie.201404664

Balzani, V., Credi, A., and Venturi, M. (2008). Photochemical conversion of solar energy. ChemSusChem 1, 26-58. doi: 10.1002/cssc.200700087

Barber, J. (2009). Photosynthetic energy conversion: natural and artificial. Chem. Soc. Rev. 38, 185-196. doi: 10.1039/B802262N

Barnett, S. M., Goldberg, K. I., and Mayer, J. M. (2012). A soluble copper-bipyridine water-oxidatzion electrocatalyst Nat. Chem. 4, 498-502. doi: $10.1038 /$ nchem. 1350

Blakemore, J. D., Schley, N. D., Balcells, D., Hull, J. F., Olack, G. W., Incarvito, C. D., et al. (2010). Half-sandwich iridium complexes for homogeneous wateroxidation catalysis. J. Am. Chem. Soc. 132, 16017-16029. doi: 10.1021/ja104775j

Bozoglian, F., Romain, S., Ertem, M. Z., Todorova, T. K., Sens, C., Mola, J., et al. (2009). The Ru-Hbpp water oxidation catalyst. J. Am. Chem. Soc. 131, 15176-15187. doi: 10.1021/ja9036127

Chuang, T. J., Brundle, C. R., and Rice, D. W. (1976). Interpretation of the x-ray photoemission spectra of cobalt oxides and cobalt oxide surfaces. Surf. Sci. 59, 413-429. doi: 10.1016/0039-6028(76)90026-1

Concepcion, J. J., Jurss, J. W., Brennaman, M. K., Hoertz, P. G., Patrocinio, A. O., Murakami Iha, N. Y., et al. (2009). Making oxygen with ruthenium complexes. Acc. Chem. Res. 42, 1954-1965. doi: 10.1021/ar9001526

Concepcion, J. J., Jurss, J. W., Templeton, J. L., and Meyer, T. J. (2008). One site is enough. catalytic water oxidation by $\left[\mathrm{Ru}(\mathrm{tpy})(\mathrm{bpm})\left(\mathrm{OH}_{2}\right)\right]^{2+}$ and $\left[\mathrm{Ru}(\mathrm{tpy})(\mathrm{bpz})\left(\mathrm{OH}_{2}\right)\right]^{2+}$. J. Am. Chem. Soc. 130, 16462-16463. doi: $10.1021 /$ ja8059649

Cook, T. R., Dogutan, D. K., Reece, S. Y., Surendranath, Y., Teets, T. S., and Nocera, D. G. (2010). Solar energy supply and storage for the legacy and nonlegacy worlds. Chem. Rev. 110, 6474-6502. doi: 10.1021/cr100246c

\section{AUTHOR CONTRIBUTIONS}

GP and JRG-M proposed the concept. GP, JRG-M, and JS-L designed the experiments. JS-L and FS carried out the experiments. All authors analyzed the data and contributed to the manuscript writing.

\section{FUNDING}

We would like to acknowledge the financial support from the Spanish Ministerio de Economía y Competitividad (MINECO) through project CTQ2015-71287-R and the Severo Ochoa Excellence Accreditation 2014-2018 SEV-2013-0319; and the Generalitat de Catalunya (2017-SGR-1406 and the CERCA Programme). GP and FS are grateful for financial support by the Swiss National Science Foundation (Sinergia Grant No. CRSII2_160801/1) and by the University Research Priority Program Solar Light to Chemical Energy Conversion (URPP LightChEC) of the University of Zurich. This collaboration took place in the context of the COST PoCheMoN action supported by the European Research Area.

\section{SUPPLEMENTARY MATERIAL}

The Supplementary Material for this article can be found online at: https://www.frontiersin.org/articles/10.3389/fchem. 2018.00302/full\#supplementary-material

Dau, H., Limberg, C., Reier, T., Risch, M., Roggan, S., and Strasser, P. (2010). The mechanism of water oxidation: from electrolysis via homogeneous to biological catalysis. ChemCatChem 2, 724-761. doi: 10.1002/cctc.201 000126

Duan, L., Bozoglian, F., Mandal, S., Stewart, B., Privalov, T., Llobet, A., et al. (2012). A molecular ruthenium catalyst with water-oxidation activity comparable to that of photosystem II. Nat. Chem. 4, 418-423. doi: 10.1038/nchem.1301

Evangelisti, F., Car, P.-E., Blacque, O., and Patzke, G. R. (2013). Photocatalytic water oxidation with cobalt-containing tungstobismutates: tuning the metal core. Catal. Sci. Technol. 3, 3117-3129. doi: 10.1039/c3cy00475a

Galán-Mascarós, J. R. (2015). Water oxidation at electrodes modified with earth-abundant transition-metal catalysts. ChemElectroChem 2, 37-50. doi: 10.1002/celc. 201402268

Gao, J., Cao, S., Tay, Q., Liu, Y., Yu, L., Ye, K., et al. (2013). Moleculebased water-oxidation catalysts (WOCs): Cluste-size-dependent dye-sensitized polyoxometalates for visible-light-driven $\mathrm{O}_{2}$ evolution. Sci. Rep. 3:1853. doi: 10.1038/srep01853

Geletii, Y. V., Botar, B., Köegerler, P., Hillesheim, D. A., Musaev, D. G., and Hill, C. L. (2008). An all-inorganic, stable, and highly active tetraruthenium homogeneous catalyst for water oxidation. Angew. Chem. Int. Ed. 47, 3896-3899. doi: 10.1002/anie.200705652

Goberna-Ferrón, S., Peña, B., Soriano-López, J., Carbó, J. J., Zhao, H., Poblet, J. M., et al. (2014). A fast metal-metal bonded water oxidation catalyst. J. Catal. 315, 25-32. doi: 10.1016/j.jcat.2014.04.010

Goberna-Ferrón, S., Soriano-López, J., Galán-Mascarós, J. R., and Nyman, M. (2015). Solution speciation and stability of cobalt-polyoxometalate water oxidation catalysts by X-ray scattering. Eur. J. Inorg. Chem. 2015, 2833-2840. doi: 10.1002/ejic.201500404

Goberna-Ferrón, S., Vigara, L., Soriano-López, J., and Galán-Mascarós, J. R. (2012). Identification of a nonanuclear $\left\{\mathrm{Co}_{9}^{\mathrm{II}}\right\}$ polyoxometalate cluster as a homogeneous catalyst for water oxidation. Inorg. Chem. 51, 11707-11715. doi: $10.1021 /$ ic $301618 \mathrm{~h}$ 
Guo, S.-X., Liu, Y., Lee, C.-Y., Bond, A. M., Zhang, J., Geletii, Y. V., et al. (2013). Graphene-supported $\left[\left\{\mathrm{Ru}_{4} \mathrm{O}_{4}(\mathrm{OH})_{2}\left(\mathrm{H}_{2} \mathrm{O}\right)_{4}\right\}\left(\gamma-\mathrm{SiW}_{10} \mathrm{O}_{36}\right)_{2}\right]^{10-}$ for highly efficient electrocatalytic water oxidation. Energy Environ. Sci. 6, 2654-2663. doi: 10.1039/c3ee41892h

Hara, M., Waraksa, C. C., Lean, J. T., Lewis, B. A., and Mallouk, T. E. (2000). Photocatalytic water oxidation in a buffered tris(2,2'-bipyridyl)ruthenium complex-colloidal $\mathrm{IrO}_{2}$ system. J. Phys. Chem. A 104, 5275-5280. doi: $10.1021 /$ jp000321x

Huang, Z., Luo, Z., Geletii, Y. V., Vickers, J. W., Yin, Q., Wu, D., et al. (2011). Efficient light-driven carbon-free cobalt-based molecular catalyst for water oxidation. J. Am. Chem. Soc. 133, 2068-2071. doi: 10.1021/ja109681d

Lewis, N. S., and Nocera, D. G. (2006). Powering the planet: chemical challenges in solar energy utilization. Proc. Natl. Acad. Sci. U.S.A. 103, 15729-15735. doi: 10.1073/pnas.0603395103

Liu, X., and Wang, F. Y. (2012). Transition metal complexes thast catalyze oxygen formation from water: 1979-2010. Coord. Chem. Rev. 256, 1115-1136. doi: 10.1016/j.ccr.2012.01.015

Lloret-Fillol, J., Codolà, Z., Garcia-Bosch, I., Gómez, L., Pla, J. J., and Costas, M. (2011). Efficient water oxidation catalysts based on readily available iron coordination complexes. Nat. Chem. 3, 807-813. doi: 10.1038/nchem.1140

Lv, H., Geletii, Y. V., Zhao, C., Vickers, J. W., Zhu, G., Luo, Z., et al. (2012). Polyoxometalate water oxidation catalysts and the production of green fuel. Chem. Soc. Rev. 41, 7572-7589. doi: 10.1039/c2cs35292c

Lv, H., Song, J., Geletii, Y. V., Vickers, J. W., Sumliner, J. M., Musaev, D. G., et al. (2014). An exceptionally fast homogeneous carbon-free cobalt-based water oxidation catalyst. J. Am. Chem. Soc. 136, 9268-9271. doi: 10.1021/ja5045488

Mccool, N. S., Robinson, D. M., Sheats, J. E., and Dismukes, G. C. (2011). $\mathrm{A} \mathrm{Co}_{4} \mathrm{O}_{4}$ "cubane" water oxidation catalyst inspired by photosynthesis. J. Am. Chem. Soc. 133, 11446-11449. doi: 10.1021/ja203877y

Mcevoy, J. P., and Brudvig, G. W. (2006). Water-splitting chemistry of photosystem II. Chem. Rev. 106, 4455-4483. doi: 10.1021/cr0204294

Natali, M., Bazzan, I., Goberna-Ferrón, S., Al-Oweini, R., Ibrahim, M., Bassil, B. S., et al. (2017). Photo-assisted water oxidation by high-nuclearity cobalt-oxo cores: tracing the catalyst fate during oxygen evolution turnover. Green Chem. 19, 2416-2426. doi: 10.1039/C7GC00052A

Pillai, K. C., Kumar, A. S., and Zen, J.-M. (2000). Nafion- $\mathrm{RuO}_{2}-\mathrm{Ru}(\mathrm{bpy})_{3}^{2+}$ composite electrodes for efficient electrocatalytic water oxidation. J. Mol. Catal. A. 160, 277-285. doi: 10.1016/S1381-1169(00)00262-4

Pope, M. T. (1983). Heteropoly and Isopoly Oxometalates. Berlin: Springer.

Pope, M. T., and Müller, A. (2001). Polyoxometalate Chemistry From Topology via Self-Assembly to Applications. Dordrecht: Kluwer Academic Publishers.

Puntoriero, F., La Ganga, G., Sartorel, A., Carraro, M., Scorrano, G., Bonchio, M., et al. (2010). Photo-induced water oxidation with tetra-nuclear ruthenium sensitizer and catalyst: a unique $4 \times 4$ ruthenium interplay triggering high efficiency with low-energy visible light. Chem. Commun. 46, 4725-4727. doi: 10.1039/c0cc00444h

Quintana, M., López, A. M., Rapino, S., Toma, F. M., Iurlo, M., Carraro, M., et al. (2013). Knitting the catalytic pattern of artificial photosynthesis to a hybrid graphene nanotexture. ACS Nano 7, 811-817. doi: 10.1021/nn305313q

Sartorel, A., Bonchio, M., Campagna, S., and Scandola, F. (2013). Tetrametallic molecular catalysts for photochemical water oxidation. Chem. Soc. Rev. 42, 2262-2268, doi: 10.1039/C2CS35287G

Sartorel, A., Carraro, M., Scorrano, G., De Zorzi, R., Geremia, S., McDaniel, N.D., et al. (2008). Polyoxometalate embedding of a tetraruthenium(IV)-oxo-core by template-directed metalation of $\left[\gamma-\mathrm{SiW}_{10} \mathrm{O}_{36}\right]^{8-}$ : a totally inorganic oxygenevolving catalyst. J. Am. Chem. Soc. 130, 5006-5007. doi: 10.1021/ja077837f
Seh, Z. W., Kibsgaard, J., Dickens, C. F., Chorkendorff, I., Nørskov, J. K., and Jaramillo, T. F. (2017). Combining theory and experiment in electrocatalysis: insights into materials design. Science 355:eaad4998. doi: 10.1126/science.aad4998

Soriano-López, J., Goberna-Ferrón, S., Vigara, L., Carbó, J. J., Poblet, J. M., and Galán-Mascarós, J. R. (2013). Cobalt polyoxometalates as heterogeneous water oxidation catalysts. Inorg. Chem. 52, 4753-4755. doi: 10.1021/ic 4001945

Stracke, J. J., and Finke, R. G. (2011). Electrocatalytic water oxidation beginning with the cobalt polyoxometalate $\left[\mathrm{Co}_{4}\left(\mathrm{H}_{2} \mathrm{O}\right)_{2}\left(\mathrm{PW}_{9} \mathrm{O}_{34}\right)_{2}\right]^{10-}$ : identification of heterogeneous $\mathrm{CoO}_{\mathrm{x}}$ as the dominant catalyst. J. Am. Chem. Soc. 133, 14872-14875. doi: 10.1021/ja205569j

Stracke, J. J., and Finke, R. G. (2013). Water oxidation catalysis beginning with $2.5 \mu \mathrm{M}\left[\mathrm{Co}_{4}\left(\mathrm{H}_{2} \mathrm{O}\right)_{2}\left(\mathrm{PW}_{9} \mathrm{O}_{34}\right)_{2}\right]^{10-}$ : investigation of the true electrochemically driven catalyst at $\geq 600 \mathrm{mV}$ overpotential at a glassy carbon electrode. ACS Catal. 3, 1209-1219. doi: 10.1021/cs400141t

Stracke, J. J., and Finke, R. G. (2014). Distinguishing Homogeneous from heterogeneous water oxidation catalysis when beginning with polyoxometalates. ACS Catal. 4, 909-933. doi: 10.1021/cs4011716

Tan, B. J., Klabunde, K. J., and Sherwood, P. M. A. (1991). XPS studies of solvated metal atom dispersed (SMAD) catalysts. Evidence for layered cobaltmanganese particles on alumina and silica. J. Am. Chem. Soc. 113, 855-861. doi: 10.1021/ja00003a019

Wu, J., Liao, L., Yan, W., Xue, Y., Sun, Y., Yan, X., et al. (2012). Polyoxometalates immobilized in ordered mesoporous carbon nitride as highly efficient water oxidation catalysts. ChemSusChem 5, 1207-1212. doi: 10.1002/cssc.201100809

Xiang, R., Ding, Y., and Zhao, J. (2014). Visible-light-induced water oxidation mediated by a mononuclear-cobalt(II)-substituted silicotungstate. Chem. Asian J. 9, 3228-3237. doi: 10.1002/asia.201402483

Xu, Y., Fischer, A., Duan, L., Tong, L., Gabrielsson, E., Åkermark, B. (2010). Chemical and light-driven oxidation of water catalyzed by an efficient dinuclear ruthenium complex. Angew. Chem. Int. Ed. 49, 8934-8937. doi: 10.1002/anie.201004278

Yin, Q., Tan, J. M., Besson, C., Geletii, Y. V., Musaev, D. G., Kuznetsov, A. E., et al. (2010). A fast soluble carbon-free molecular water oxidation catalyst based in abundant metals. Science 328, 342-345. doi: 10.1126/science. 1185372

Youngblood, W. J., Lee, S. H. A., Kobayashi, Y., Hernandez-Pagan, E. A., Hoertz, P. G., Moore, T. A., et al. (2009). Photoassisted overall water splitting in a visible light-absorbing dye-sensitized photoelectrochemical cell. J. Am. Chem. Soc. 131, 926-927. doi: 10.1021/ja809108y

Zhang, M. T., Chen, Z., Kang, P., and Meyer, T. J. (2013). Electrocatalytic water oxidation with a copper(II) polypeptide complex. J. Am. Chem. Soc. 135, 2048-2051. doi: 10.1021/ja3097515

Conflict of Interest Statement: The authors declare that the research was conducted in the absence of any commercial or financial relationships that could be construed as a potential conflict of interest.

Copyright (c) 2018 Soriano-López, Song, Patzke and Galan-Mascaros. This is an open-access article distributed under the terms of the Creative Commons Attribution License (CC BY). The use, distribution or reproduction in other forums is permitted, provided the original author(s) and the copyright owner(s) are credited and that the original publication in this journal is cited, in accordance with accepted academic practice. No use, distribution or reproduction is permitted which does not comply with these terms. 